\title{
FAKTOR-FAKTOR YANG BERHUBUNGAN DENGAN TEKANAN DARAH PASIEN HIPERTENSI
}

\author{
Ninda Putri Ramarianda, Kamsiah \\ Politeknik Kesehatan Kementerian Kesehatan Bengkulu, Jurusan Gizi, \\ Jalan Indragiri Nomor 03 Padang Harapan Kota Bengkulu \\ nindaputriramarianda@gmail.com
}

\begin{abstract}
Hypertension is often referred to as the silent killer. Hypertension is a condition of elevated blood pressure in the arteries that lead to increased risk for stroke, aneurysm, heart failure, heart attack and kidney damage. Some of the causes of hypertension were age, sex, carbohydrate intake, saturated fat and unsaturated fat. The purpose of this study to determine the factors that most influence the blood pressure of hypertensive patients. This type of research analytic survey with a cross-sectional design with independent variables (age, sex, carbohydrate intake, saturated fat and unsaturated fat) and the dependent variable (blood pressure). Total population of 476 hypertensive patients. Samples taken by accidental sampling. The Total samples is 83 . The results showed that there is a significant relationship between age, intake of carbohydrates, saturated fat and unsaturated fat with blood pressure. There is no significant difference in blood pressure between the sexes. The most dominant factor is the systolic blood pressure is age and diastolic blood pressure is carbohydrate intake.
\end{abstract}

Keywords: Age, Gender, Intake (Carbohydrates, Saturated Fats, Unsaturated Fats), Blood Pressure, Hypertension

\begin{abstract}
Abstrak : Hipertensi seringkali disebut sebagai pembunuh diam-diam (silent killer). Hipertensi merupakan suatu keadaan peningkatan tekanan darah di dalam arteri yang menyebabkan meningkatnya risiko terhadap stroke, aneurisma, gagal jantung, serangan jantung dan kerusakan ginjal. Beberapa penyebab terjadinya hipertensi adalah umur, jenis kelamin, asupan karbohidrat, lemak jenuh, dan lemak tak jenuh. Tujuan penelitian ini untuk mengetahui faktor yang paling mempengaruhi tekanan darah pasien hipertensi. Jenis penelitian ini survey analitik dengan desain cross-sectional dengan variabel independen (umur, jenis kelamin, asupan karbohidrat, lemak jenuh, dan lemak tak jenuh) dan variabel dependen (tekanan darah). Jumlah populasi pasien hipertensi 476 orang. Sampel diambil secara Accidental Sampling. Jumlah sampel adalah 83 orang. Hasil penelitian menunjukkan bahwa ada hubungan yang bermakna antara umur, asupan karbohidrat, lemak jenuh, dan lemak tak jenuh dengan tekanan darah. Tidak ada perbedaan yang bermakna tekanan darah menurut jenis kelamin. Faktor yang paling dominan dengan tekanan darah sistolik adalah umur dan tekanan darah diastolik adalah asupan karbohidrat.
\end{abstract}

Kata Kunci: Umur, Jenis Kelamin, Asupan (Karbohidrat, Lemak Jenuh, Lemak Tak Jenuh), Tekanan Darah, Hipertensi

Hasil survei yang dilakukan World Health Organization pada tahun 2000, jumlah penduduk dunia yang menderita hipertensi untuk pria sekitar $26,6 \%$ dan wanita sekitar $26,1 \%$ dan diperkirakan pada tahun 2025 jumlahnya akan meningkat menjadi 29,2\% (Yogiantoro M, 2006). Meningkatnya prevalensi penyakit kardiovaskuler setiap tahun menjadi masalah utama di negara berkembang dan negara maju. Berdasarkan data Global Burden of Disease (GBD) tahun 2000, 50\% dari penyakit kardiovaskuler disebabkan oleh hipertensi (Shapo L, dkk, 2003).
Di Indonesia prevalensi penderita hipertensi terus meningkat. Hasil Survei Kesehatan Rumah Tangga (SKRT) pada tahun 2000 sebesar $21 \%$ menjadi $26,4 \%$ pada tahun 2001 dan $27,5 \%$ pada tahun 2004 . Selanjutnya diperkirakan meningkat lagi menjadi $37 \%$ pada tahun 2015 dan menjadi $45 \%$ pada tahun 2025 (Depkes RI, 2011). Berdasarkan data Profil Kesehatan Kota Bengkulu penyakit hipertensi termasuk ke dalam 10 besar penyakit tidak menular terbanyak di Kota Bengkulu (Dinkes Bengkulu, 2006).

Hipertensi seringkali disebut sebagai pembunuh diam-diam (silent killer). Hipertensi 
merupakan suatu keadaan dimana tekanan darah yang abnormal tinggi di dalam arteri menyebabkan meningkatnya risiko terhadap stroke, aneurisma, gagal jantung, serangan jantung dan kerusakan ginjal. Seseorang dikatakan mengalami hipertensi jika memiliki tekanan darah sistolik $>140 \mathrm{mmHg}$ atau tekanan darah diastolik $\searrow 0 \mathrm{mmHg}$ atau keduanya (Ridwan, 2009).

Beberapa faktor risiko yang berpengaruh terhadap kenaikan tekanan darah seseorang yaitu umur, jenis kelamin, asupan karbohidrat, asupan lemak jenuh, dan asupan lemak tak jenuh. Hipertensi meningkat sejalan dengan pertambahan umur. Tekanan darah sistolik terus meningkat sampai usia 80 tahun dan tekanan darah diastolik terus meningkat sampai usia 55-60 tahun (Krummel, 2004).

Selain umur, faktor gender (jenis kelamin) juga berpengaruh pada terjadinya hipertensi, dimana pria lebih banyak dibandingkan wanita. Namun memasuki menepouse prevalensi hipertensi pada wanita meningkat (Depkes, 2006). Hal tersebut dikarenakan adanya pengaruh hormon estrogen (Gray, 2005).

Asupan makanan yang dapat memicu terjadinya hipertensi yaitu makanan yang mengandung karbohidrat tinggi karena menghasilkan energi yang tinggi selanjutnya disimpan tubuh sebagai cadangan lemak. Penumpukan lemak tubuh pada pembuluh darah akan menyumbat peredaran darah dan membentuk plak (aterosklerosis) yang berdampak pada hipertensi. Menurut penelitian Johnson et al. (2007), dosis karbohidrat sederhana yang tinggi dapat meningkatkan tekanan darah dan perubahan mikrovaskular.

Faktor makanan lain yang dapat menyebabkan hipertensi yaitu asupan lemak jenuh. Jika tubuh mengkonsumsi bahan makanan yang mengandung lemak jenuh secara berlebihan, maka akan menyebabkan peningkatan kadar LDL kolesterol yang dapat menyebabkan terjadinya ateroklerosis. Akibatnya, pembuluh darah makin sempit dan elastisitasnya berkurang. Perubahan ini dapat meningkatkan tekanan darah (Cahyono, 2008). Sebaliknya, Lemak tidak jenuh memberikan efek hipokolesterolemik dengan menurunkan kadar LDL kolesterol dalam darah dan meningkatkan kadar HDL kolesterol sehingga mengurangi resiko penyakit aterosklerosis dan kardiovaskuler (Adkins dan Darshan, 2010).

Berdasarkan data yang diperoleh dari medical record RSUD Dr. M. Yunus Bengkulu, tercatat pada tahun 2010 prevalensi penyakit hipertensi atau tekanan darah tinggi menduduki peringkat 1 yaitu dengan jumlah 5381 orang dan presentase $5,10 \%$ dari total pasien rawat jalan tahun 2010. Pada tahun 2011 pasien hipertensi berjumlah 4306 orang dengan jumlah kasus baru 466 orang. Pada tahun 2012 penyakit hipertensi menduduki peringkat 1 dari 10 besar penyakit rawat jalan lainnya dengan jumlah pasien sebanyak 5342 pasien $(5,32 \%)$. Sedangkan pada tahun 2013 jumlah pasien hipertensi rawat jalan dari bulan Januari-April yaitu 476 pasien $(3,59 \%)$. Tujuan penelitian ini untuk mengetahui faktor yang paling mempengaruhi tekanan darah pasien hipertensi.

\section{BAHAN DAN CARA KERJA}

Penelitian ini merupakan penelitian survey analitik dengan desain cross-sectional. Polpulasi pada penelitian ini adalah semua pasien hipertensi dengan diagnosa penyakit hipertensi di poli penyakit dalam RSUD dr. M. Yunus Bengkulu tahun 2013 yang berjumlah 476 orang. Sampel yang diambil adalah pasien hipertensi yang menjalani rawat jalan di Poli Penyakit Dalam di RSUD dr. M. Yunus yang memenuhi kriteria. Teknik pengambilan sampel adalah dengan metode Accidental Sampling. Besar sampel yang digunakan adalah 83 orang. Data dianalisis secara univariat yang menggunakan uji deskriptif statistik, analisis bivariat yang menggunakan uji t untuk variabel yang berbentuk katagorik dan uji korelasi untuk variabel yang berbentuk numerik, dan analisis multivariat menggunakan uji regresi linier berganda karena variabel dependen berbentuk numerik.

\section{HASIL}

\section{Analisis Univariat}

Berdasarkan Tabel 1 dapat diketahui bahwa hampir seluruh sampel berusia $>40$ tahun 
dengan persentase sebesar $80,8 \%$ dan sebanyak $63,9 \%$ sampel pada penelitian ini berjenis kelamin perempuan dan $36,1 \%$ sisanya adalah laki-laki.

Tabel 1. Distribusi Sampel Berdasarkan Umur dan Jenis Kelamin

\begin{tabular}{lcc}
\hline \multicolumn{1}{c}{ Variabel } & $\begin{array}{c}\text { Frekuensi } \\
\text { (Orang) }\end{array}$ & Persentase (\%) \\
\hline Umur & 16 & 19,2 \\
$\leq 40$ & 67 & 80,8 \\
$>40$ & 83 & 100 \\
Jumlah & & \\
Jenis Kelamin & 30 & 36,1 \\
Laki-Laki & 53 & 63,9 \\
Perempuan & 53 \\
\hline
\end{tabular}

Tabel 2. Distribusi Sampel Berdasarkan Asupan Karbohidrat, Lemak Jenuh, dan Lemak Tak Jenuh

\begin{tabular}{lccccccc}
\hline Variabel & N & Mean & SD & Min & Mak & Ref & St \\
\hline $\begin{array}{l}\text { Asupan } \\
\text { Karbohidr }\end{array}$ & 83 & 377,1 & 93,92 & 205,7 & 684,7 & 375 & $\mathrm{~g}$ \\
at & & & & & & & \\
$\begin{array}{l}\text { Asupan } \\
\text { Lemak }\end{array}$ & 83 & 32,1 & 7,37 & 20,3 & 48,0 & 20 & $\mathrm{~g}$ \\
$\begin{array}{l}\text { Jenuh } \\
\text { Asupan }\end{array}$ & 83 & 11,5 & 2,16 & 8,0 & 16,8 & 15,5 & $\mathrm{~g}$ \\
$\begin{array}{l}\text { Lemak } \\
\text { Tidak }\end{array}$ & & & & & & & \\
Jenuh & & & & & & & \\
\hline
\end{tabular}

Berdasarkan Tabel 2 terlihat bahwa ratarata asupan karbohidrat responden adalah 377 , 1 g dengan nilai minimum 205,7 g dan nilai maksimum 684,7 g. Rata-rata asupan lemak jenuh responden adalah $32,1 \mathrm{~g}$ dengan nilai minimum 20,3 g dan nilai maksimum 48,0 g. Rata-rata asupan lemak tidak jenuh responden adalah $11,5 \mathrm{~g}$ dengan nilai minimum $8,0 \mathrm{~g}$ dan nilai maksimum $16,8 \mathrm{~g}$.

Tabel 3. Distribusi Sampel Berdasarkan Tekanan Darah

\begin{tabular}{lcccccc}
\hline \multicolumn{1}{c}{ Variabel } & N & Mean & SD & Min & Mak & Ref \\
\hline $\begin{array}{l}\text { Tekanan } \\
\begin{array}{l}\text { Darah } \\
\text { Sistolik }\end{array}\end{array}$ & 83 & 150 & 11,15 & 130 & 170 & $\begin{array}{c}130- \\
\text { Tekanan }\end{array}$ \\
$\begin{array}{l}\text { Darah } \\
\text { Diastolik }\end{array}$ & 83 & 96,39 & 4,83 & 90 & 100 & $85-89$ \\
\hline
\end{tabular}

Berdasarkan Tabel 3 diketahui bahwa hasil pemeriksaan tekanan darah responden didapatkan rata-rata tekanan darah sistolik yaitu $150 \mathrm{mmHg}$ dan diastolik $96,39 \mathrm{mmHg}$ yang termasuk dalam katagori hipertensi derajat 1 (sistolik : 140-159/ diastolik : 90-99 mmHg).
Nilai minimum tekanan darah sistolik yaitu 130 $\mathrm{mmHg}$ dan diastolik $90 \mathrm{mmHg}$. Nilai maksimum tekanan darah sistolik yaitu 170 $\mathrm{mmHg}$ dan diastolik $100 \mathrm{mmHg}$.

\section{Analisis Bivariat}

Analisis ini dilakukan untuk mengetahui hubungan variabel bebas dengan variabel terikat dengan uji statistic t-test untuk variabel yang berbentuk katagorik dan uji statistic korelasi untuk variabel yang berbentuk numerik.

Tabel 4. Hubungan Umur dengan Tekanan Darah Penderita Hipertensi di Poli Penyakit Dalam RSUD dr. M. Yunus Bengkulu Tahun 2013

\begin{tabular}{lcccc}
\hline \multirow{2}{*}{ Variabel } & \multicolumn{4}{c}{ Tekanan Darah Sistolik } \\
\cline { 2 - 5 } & $\mathbf{R}$ & $\mathbf{P}$ & $\mathbf{R}$ & $\mathbf{p}$ \\
\hline $\begin{array}{l}\text { Umur dengan } \\
\text { Tekanan Darah }\end{array}$ & 0,498 & 0,000 & 0,317 & 0,003 \\
$\begin{array}{l}\text { Asupan } \\
\text { Karbohidrat dengan } \\
\text { Tekanan Darah }\end{array}$ & 0,354 & 0,001 & 0,296 & 0,007 \\
$\begin{array}{l}\text { Asupan Lemak } \\
\text { Jenuh dengan }\end{array}$ & 0,355 & 0,001 & 0,310 & 0,004 \\
$\begin{array}{l}\text { Tekanan Darah } \\
\text { Asupan Lemak Tak }\end{array}$ & & & & \\
Jenuh dengan \\
Tekanan Darah
\end{tabular}

Berdasarkan Tabel 4 dapat diketahui bahwa hubungan umur dengan tekanan darah sistolik dan diastolik menunjukan hubungan yang sedang $(\mathrm{r}=0,498 / 0,317)$ dan koefisien korelasi menunjukan arah korelasi positif artinya semakin bertambahnya umur maka resiko hipertensi akan lebih tinggi. Hasil uji hipotesis menunjukkan adanya hubungan yang signifikan antara umur dengan tekanan darah sistolik dan diastolik, hal ini ditunjukkan oleh nilai $\mathrm{p}$ value $0,000<0,05$ dan nilai $\mathrm{p}$ value $0,003<0,05$.

Dari hasil uji korelasi didapat hubungan antara asupan karbohidrat dengan tekanan darah sistolik dan diastolik menunjukkan hubungan sedang $(r=0,354 / 0,296)$ dan koefesien korelasi menunjukan arah korelasi positif artinya semakin tinggi asupan karbohidrat maka tekanan darah akan semakin tinggi. Hasil uji hipotesis menunjukkan adanya hubungan yang signifikan antara asupan karbohidrat dengan tekanan darah sistolik dan diastolik, hal ini ditunjukkan oleh nilai $\mathrm{p}$ value $0,001<0,05$ dan nilai $\mathrm{p}$ value $0,007<0,05$. 
Dari hasil uji korelasi didapat hubungan antara asupan lemak jenuh dengan tekanan darah sistolik dan diastolik menunjukkan hubungan sedang $(\mathrm{r}=0,355 / 0,310)$ dan koefesien korelasi menunjukan arah korelasi positif artinya semakin tinggi asupan lemak jenuh maka tekanan darah akan semakin tinggi. Hasil uji hipotesis menunjukkan adanya hubungan yang signifikan antara asupan lemak jenuh dengan tekanan darah sistolik dan diastolik, hal ini ditunjukkan oleh nilai $\mathrm{p}$ value $0,001<0,05$ dan nilai $\mathrm{p}$ value $0,004<0,05$.

Dari hasil uji korelasi didapat hubungan asupan lemak tidak jenuh dengan tekanan darah sistolik dan diastolik menunjukkan hubungan yang sedang $(\mathrm{r}=-0,373 /-0,290)$ dengan koefisien korelasi menunjukan arah korelasi negatif artinya semakin tinggi asupan lemak tidak jenuh maka tekanan darah akan semakin rendah. Hasil uji hipotesis menunjukkan adanya hubungan yang signifikan antara asupan lemak tak jenuh dengan tekanan darah sistolik dan diastolik, hal ini ditunjukkan oleh nilai $\mathrm{p}$ value $0,001<0,05$ dan nilai $\mathrm{p}$ value $0,008<0,05$.

Berdasarkan tabel 5 terlihat bahwa ratarata tekanan darah sistolik penderita hipertensi yang berjenis kelamin laki-laki adalah 151,33 \pm 11,366 lebih besar dibandingkan dengan tekanan darah sistolik penderita hipertensi yang berjenis kelamin perempuan yaitu 149,25 \pm 11,068 dengan perbedaan 2,088. Dari hasil uji t-test independen tidak terdapat perbedaan yang bermakna $(\mathrm{p}=0,864>0,05)$ rata-rata tekanan darah sistolik antara penderita hipertensi lakilaki dengan perempuan.

Berdasarkan tabel 5 juga dapat diketahui rata-rata tekanan darah diastolik penderita hipertensi yang berjenis kelamin laki-laki adalah 96,67 \pm 4,795 lebih besar dibandingkan dengan tekanan darah sistolik penderita hipertensi yang berjenis kelamin perempuan yaitu 96,23 \pm 4,894 dengan perbedaan 0,440. Dari hasil uji t-test independen tidak terdapat perbedaan yang bermakna $(\mathrm{p}=0,413>0,05)$ rata-rata tekanan darah diastolik antara penderita hipertensi laki-laki dengan perempuan.

\section{Analisis Multivariat}

Analisis multivariat bertujuan untuk mendapatkan variabel yang paling berpengaruh dengan tekanan darah melalui analisis regresi linier berganda. Pada analisis multivariat terlebih dahulu dilakukan penyaringan terhadap variabel bebas yang akan menjadi kandidat untuk dimasukkan dalam model. Variabel bebas yang akan masuk dalam model adalah variabel yang mempunyai hubungan dengan tekanan darah dengan nilai $\mathrm{p} \leq 0,25$. Adapun hasil analisis multivariat tersebut adalah sebagai berikut:

Berdasarkan hasil uji multivariat diketahui bahwa jenis kelamin mempunyai $p$ value terbesar sehingga variabel jenis kelamin dikeluarkan dari model pertama. Pada pemodelan kedua tinggal variabel umur, asupan karbohidrat, lemak jenuh, dan lemak tak jenuh. Pada model kedua terlihat bahwa asupan karbohidrat mempunyai $p$ value terbesar sehingga variabel asupan karbohidrat harus keluar dari model kedua. Pada model ketiga terdapat tiga variabel yang masuk dalam model dengan $\mathrm{p}$ value $<0,05$ yaitu umur, asupan lemak jenuh dan lemak tak jenuh.

Berdasarkan tabel 6 diatas dapat dijelaskan bahwa variabel yang berhubungan dengan tekanan darah sistolik penderita hipertensi di poli penyakit dalam RSUD dr. M. Yunus Bengkulu adalah variabel umur, asupan lemak jenuh, dan asupan lemak tak jenuh. Variabel yang paling dominan dengan tekanan darah sistolik adalah umur yang dapat dilihat dari nilai beta variabel umur 0,418 yang merupakan beta terbesar dari seluruh variabel yang masuk ke dalam model multivariat.

Berdasarkan hasil uji multivariat diketahui bahwa jenis kelamin mempunyai $p$ value terbesar sehingga variabel jenis kelamin dikeluarkan dari model pertama. Pada pemodelan kedua tinggal variabel umur, asupan karbohidrat, lemak jenuh, dan lemak tak jenuh. Pada model kedua terlihat bahwa umur mempunyai $\mathrm{p}$ value terbesar sehingga variabel umur harus keluar dari model kedua. Pada model ketiga terdapat tiga variabel yang masuk dalam model dengan $\mathrm{p}$ value $<0,05$ yaitu asupan karbohidrat, lemak jenuh, dan lemak tak jenuh. 
Tabel 5. Hubungan Jenis Kelamin dengan Tekanan Darah Penderita Hipertensi di Poli Penyakit Dalam RSUD dr. M. Yunus Bengkulu Tahun 2013

\begin{tabular}{lccccccc}
\hline \multirow{2}{*}{ Variabel } & \multicolumn{2}{c}{ Tekanan Darah Sistolik } & \multicolumn{2}{c}{ Tekanan Darah Sistolik } & \multirow{2}{*}{ N } \\
\cline { 2 - 6 } & Rerata \pm SD & SE & p & Rerata \pm SD & SE & p & \\
\hline Laki-laki & $151,33 \pm 11,366$ & 2,075 & \multirow{2}{*}{0,864} & $96,67 \pm 4,795$ & 0,875 & 30 \\
Perempuan & $149,25 \pm 11,068$ & 1,520 & & $96,23 \pm 4,894$ & 0,672 & 0,413 & 53 \\
\hline
\end{tabular}

Tabel 6. Hasil Analisis Akhir Multivariat Regresi Linier antara Umur, Lemak Jenuh, dan Lemak Tak Jenuh dengan Tekanan Darah Sistolik

\begin{tabular}{lcccc}
\hline \multicolumn{1}{c}{ Variabel } & B & SE & Beta & P value \\
\hline Umur & 0,545 & 0,118 & 0,418 & 0,000 \\
$\begin{array}{l}\text { Asupan } \\
\text { Lemak }\end{array}$ & 0,365 & 0,138 & 0,241 & 0,010 \\
$\begin{array}{l}\text { Jenuh } \\
\text { Asupan }\end{array}$ & & & & \\
$\begin{array}{l}\text { Lemak Tak } \\
\text { Jenuh }\end{array}$ & $-1,264$ & 0,472 & $-0,245$ & 0,009 \\
\hline
\end{tabular}

Tabel 7. Hasil Analisis Akhir Multivariat Regresi Linier antara Asupan Karbohidrat, Lemak Jenuh, dan Lemak Tak Jenuh dengan Tekanan Darah Diastolik

\begin{tabular}{lcccc}
\hline \multicolumn{1}{c}{ Variabel } & B & SE & Beta & P value \\
\hline $\begin{array}{l}\text { Asupan } \\
\text { Karbohidrat } \\
\text { Asupan Lemak }\end{array}$ & 0,014 & 0,005 & 0,265 & 0,010 \\
$\begin{array}{l}\text { Jenuh } \\
\begin{array}{l}\text { Asupan Lemak } \\
\text { Tak Jenuh }\end{array}\end{array}$ & $-0,168$ & 0,067 & 0,257 & 0,014 \\
\hline
\end{tabular}

Berdasarkan tabel 7 diatas dapat dijelaskan bahwa variabel yang berhubungan dengan tekanan darah diastolik penderita hipertensi di poli penyakit dalam RSUD dr. M. Yunus Bengkulu adalah variabel asupan karbohidrat, lemak jenuh, dan asupan lemak tak jenuh. Variabel yang paling dominan dengan tekanan darah diastolik adalah asupan karbohidrat yang dapat dilihat dari nilai beta variabel asupan karbohidrat 0,265 yang merupakan beta terbesar dari seluruh variabel yang masuk ke dalam model multivariat.

\section{PEMBAHASAN}

\section{Hubungan Umur dengan Tekanan Darah}

Hasil penelitian ini menunjukkan bahwa proporsi pasien hipertensi yang berumur $>40$ tahun lebih banyak dibandingkan dengan pasien hipertensi yang berumur $\leq 40$ tahun. Hal ini sesuai dengan fakta bahwa tanda-tanda penuaan dan munculnya penyakit degeneratif mulai terlihat pada umur 40 tahun keatas.
Dengan bertambahnya umur, risiko terkena hipertensi menjadi lebih besar.

Penyakit hipertensi paling banyak dialami oleh kelompok umur 31-55 tahun dan umumnya berkembang pada saat berusia lebih dari 40 tahun. Setelah usia 45 tahun terjadi peningkatan resistensi perifer dan aktivitas simpatik. Dinding arteri akan mengalami penebalan oleh karena adanya penumpukan zat kolagen pada lapisan otot, sehingga pembuluh darah akan berangsur-angsur menyempit dan menjadi kaku. Disamping itu, pada usia lanjut sensitivitas pengaturan tekanan darah yaitu refleks baroreseptor mulai berkurang, demikian juga halnya dengan peran ginjal, dimana aliran darah ginjal dan laju filtrasi glomerulus menurun yang dapat menyebabkan naiknya tekanan darah (Kumar, et all, 2005).

Berdasarkan hasil analisis uji korelasi pearson, didapatkan hasil adanya hubungan yang bermakna antara umur dengan tekanan darah sistolik $(\mathrm{p}=0,000 ; \mathrm{r}=0,498)$ dan diastolik $(\mathrm{p}=0,003 ; \mathrm{r}=0,317)$. Hasil penelitian ini sejalan dengan penelitian yang dilakukan oleh Aisyiyah (2009) diketahui bahwa ada hubungan nyata positif antara umur dan hipertensi. Penelitian Irza (2009) menyatakan bahwa resiko hipertensi 17 kali lebih tinggi pada subjek $>40$ tahun dibandingkan dengan yang berusia $\leq$ 40 tahun. Berarti diketahui bahwa meningkatnya umur seseorang akan diikuti dengan meningkatnya kejadian hipertensi.

\section{Hubungan Jenis Kelamin dengan Tekanan Darah}

Hasil penelitian ini menunjukkan bahwa proporsi pasien hipertensi berjenis kelamin perempuan lebih banyak dibandingkan dengan pasien hipertensi berjenis kelamin laki-laki. Hal tersebut sejalan dengan pendapat Gray (2005) bahwa di usia 45 tahun keatas wanita di- 
pengaruhi oleh hormon estrogen yang dapat melindungi tubuh dari penyakit kardiovaskuler.

Berdasarkan hasil uji statistik t-test independent diperoleh tidak terdapatnya perbedaan yang bermakna antara jenis kelamin laki-laki dan perempuan dengan tekanan darah sistolik $(\mathrm{p}=0,864)$ dan diastolik $(\mathrm{p}=0,431)$. Hasil penelitian yang dilakukan oleh Sulistiani (2005) juga menunjukkan tidak terdapat hubungan yang signifikan antara jenis kelamin dengan kejadian hipertensi.

Hal tersebut kemungkinan disebabkan karena responden mengkonsumsi obat-obatan hipertensi yang dapat mempengaruhi penurunan tekanan darah. Selain itu kemungkinan juga dapat disebabkan oleh telah menebalnya dinding arteri akibat dari akumulasi menumpuknya zat kolagen pada lapisan otot selama bertahun-tahun, yang berdampak pada penyempitan dan pengerasan pembuluh darah, Sehingga hal-hal tersebut dapat memicu timbulnya hipertensi tanpa memandang jenis kelamin lakilaki ataupun perempuan (Kumar, et all, 2005).

Price dan Wilson (2002) menambahkan bahwa penyebab hipertensi dapat disebabkan pula oleh penurunan elastisitas pembuluh darah sehingga pembuluh darah menjadi kaku. Pembuluh darah tidak dapat menjalankan fungsinya dengan baik untuk mengembang pada saat jantung memompa darah melalui pembuluh darah tersebut. Sehingga jantung harus meningkatkan denyutnya pada pembuluh darah yang menyempit agar aliran darah dapat didistribusikan keseluruh tubuh. Hal ini menyebabkan naiknya tekanan darah.

\section{Hubungan Asupan Karbohidrat dengan Tekanan Darah}

Dari hasil penelitian didapatkan rata-rata asupan karbohidrat yang dikonsumsi oleh pasien hipertensi yaitu 377,08 gr. Berdasarkan hasil tersebut, dapat diketahui bahwa tingkat konsumsi karbohidrat responden melebihi standar yang dianjurkan yaitu $75 \%$ dari kebutuhan energi total atau sekitar 375 gr.

Dilihat dari karakteristik responden sering mengkonsumsi gula, sirup, teh manis, dan makanan olahan seperti martabak yang merupakan sumber karbohidrat sederhana. Konsumsi karbohidrat sederhana yang tinggi dapat meningkatkan tekanan darah dan perubahan mikrovaskular (Johnson et al, 2007). Konsumsi karbohidrat sederhana akan meningkatkan gula darah sesaat setelah dikonsumsi. Meningkatnya gula darah akan meningkatkan heart rate dimana jantung memompa darah lebih cepat sehingga meningkatkan cardiac output dan terjadi peningkatan tekanan darah yang menyebabkan hipertensi (Clive, et all, 2008).

Berdasarkan hasil analisis uji korelasi pearson, didapatkan hasil adanya hubungan yang bermakna antara asupan karbohidrat dengan tekanan darah sistolik $(\mathrm{p}=0,001 ; \mathrm{r}=$ $0,354)$ dan diastolik ( $p=0,003 ; r=0,296)$. Hasil penelitian ini sejalan dengan penelitian yang dilakukan oleh Derris Sugianty (2008) yang menunjukkan bahwa adanya hubungan yang signifikan antara asupan karbohidrat dengan tekanan darah sistolik dan diastolik.

\section{Hubungan Asupan Lemak Jenuh dengan Tekanan Darah}

Penelitian ini menunjukkan bahwa ratarata asupan lemak jenuh yang dikonsumsi oleh pasien hipertensi yaitu 32,09 gr, hal ini menunjukkan bahwa asupan lemak jenuh responden sudah lebih dari asupan lemak jenuh yang dianjurkan yaitu $10 \%$ dari kebutuhan energi total atau sekitar 20 gr.

Lemak jenuh memang diperlukan oleh tubuh sebagai zat pelindung dan pembangun. Tetapi, apabila konsumsinya berlebihan dapat menimbulkan hipertensi. Patofisiologi metabolisme lemak jenuh sehingga menyebabkan hipertensi adalah dimulai ketika kolesterol yang banyak terdapat dalam LDL akan menumpuk pada dinding pembuluh darah dan membentuk plak. Plak akan bercampur dengan protein dan ditutupi oleh sel-sel otot dan kalsium yang akhirnya berkembang menjadi aterosklerosis. Pembuluh darah koroner yang menderita aterosklerosis selain menjadi tidak elastis, juga mengalami penyempitan sehingga tekanan aliran darah dalam pembuluh koroner juga naik, yang menyebabkan terjadinya hipertensi (Vilareal, 2008).

Berdasarkan hasil analisis uji korelasi pearson, didapatkan hasil adanya hubungan yang bermakna antara asupan lemak jenuh dengan tekanan darah sistolik $(\mathrm{p}=0,000 ; \mathrm{r}=$ 
$0,355)$ dan diastolik $(\mathrm{p}=0,002 ; \mathrm{r}=0,310)$. Hasil penelitian ini sejalan dengan penelitian yang dilakukan oleh Sugihartono (2007) yang menyatakan bahwa sering mengkonsumsi lemak jenuh mempunyai resiko untuk terserang hipertensi sebesar 7,72 kali dibandingkan orang yang tidak biasa mengkonsumsi lemak jenuh. Hal ini diperkuat dengan hasil penelitian yang dilakukan oleh Rumu (2007) yang mendapatkan adanya hubungan yang bermakna antara asupan lemak jenuh dengan tekanan darah pada penderita hipertensi.

\section{Hubungan Asupan Lemak Tak Jenuh dengan Tekanan Darah}

Hasil penelitian ini menunjukkan bahwa rata-rata asupan lemak tak jenuh yang dikonsumsi oleh pasien hipertensi yaitu 11,51 gr, hal ini menunjukkan bahwa asupan lemak tak jenuh responden lebih rendah dari asupan lemak tak jenuh yang dianjurkan yaitu $7 \%$ dari kebutuhan energi total atau sekitar 15,5 gr.

Lemak tak jenuh dapat mempengaruhi tekanan darah dengan memberikan efek hipokolesterolemik dengan menurunkan kadar kolesterol jahat (Low Desinty Lipoprotein/LDL) dalam darah dan meningkatkan kadar kolesterol baik (High Desinty Lipoprotein/HDL). Dengan efek hipokolesterolemik asam lemak tidak jenuh dapat menurunkan kadar kolesterol dalam darah sehingga mengurangi resiko penyakit aterosklerosis dan kardiovaskuler (Adkins dan Darshan, 2010).

Berdasarkan hasil analisis uji korelasi pearson, didapatkan hasil adanya hubungan yang bermagna antara asupan lemak tak jenuh dengan tekanan darah sistolik $(\mathrm{p}=0,000 ; \mathrm{r}=$ $0,373)$ dan diastolik $(p=0,004 ; r=-0,290)$.

\section{DAFTAR RUJUKAN}

Adkins Y, Darshan SK. 2010. Mechanims Underlying the Cardioprotective Effect of Omega-3 Polyunsaturated Fatty Acid. J Nut Bio 2010. Volume 8. No. 30. Page 521-528.

Aisyiyah, Farida Nur. 2009. Faktor Risiko Hipertensi pada Empat Kabupaten/Kota dengan Prevalensi Hipertensi Tertinggi Di Jawa dan Sumatera. Bogor: Departemen gizi masyarakat Fakultas Ekologi Manusia IPB. Jurnal Kesehatan Volume 22. No. 4. Hal. 185-190.
Hasil penelitian ini sejalan dengan penelitian yang dilakukan oleh Zuhro Agustini, dkk (2012) menunjukkan bahwa ada hubungan yang signifikan antara asupan lemak tak jenuh dengan tekanan darah sistolik dan diastolik. Simon-Morton (2006) juga menyatakan asupan asam lemak tidak jenuh berhubungan dengan tekanan darah sistolik dan diastolik.

\section{KESIMPULAN}

Sebagian besar penderita hipertensi di RSUD dr. M. Yunus Bengkulu berusia lebih dari empat puluh tahun dan berjenis kelamin perempuan. Rata-rata asupan karbohidrat dan lemak jenuh responden sudah lebih dari yang dianjurkan. Rata-rata asupan lemak tidak jenuh responden masih kurang dari yang dianjurkan. Rata-rata tekanan darah responden termasuk dalam katagori hipertensi derajat satu.

Ada hubungan yang bermakna antara umur, asupan karbohidrat, lemak jenuh dan lemak tak jenuh dengan tekanan darah penderita hipertensi di RSUD dr. M. Yunus Bengkulu. Tidak ada perbedaan yang bermakna tekanan darah menurut jenis kelamin. Faktor yang paling dominan terhadap tekanan darah sistolik adalah variabel umur, sedangkan faktor yang paling dominan terhadap tekanan darah diastolik adalah variabel asupan karbohidrat. Diharapkan Instalasi Gizi RSUD dr. M.Yunus Bengkulu dapat memberikan penyuluhan secara khusus kepada pasien hipertensi mengenai asupan lemak (lemak jenuh dan lemak tak jenuh) dan pemilihan bahan makanan untuk diet penyakit hipertensi, sehingga pasien dapat menerapkan pola hidup sehat.

Cahyono, Suharjo. 2008. Gaya Hidup dan Penyakit Modern. Jakarta: Kanisius.

Clive MB, Abdul GD, Gayathri Y, Montani JP. 2008. Fructose Ingestion Acutely Elevates Blood Pleasure in Healthy Young Human. Am J Physiol Regular Integr Comp Phsiol. Volume 3. No. 6. p 741-749.

Gray, Huon. 2005. Kardiologi Edisi IV. Jakarta: Erlangga.

Irza, Syukraini. 2009. Jurnal Analisis Faktor-Faktor Risiko Hipertensi pada Masyarakat Nagari Bungo 
Tanjung, Sumatera Barat. Fakultas Farmasi USU. Volume 10. No. 2. Hal. 78-88.

Johnson et al. 2007. Potential role of sugar (fructose) in the epidemic of hypertension, obesity and the metabolic syndrome, diabetes, kidney disease, and cardiovascular disease. Am J Clin Nutr Volume 17. Issu 6. p 397.

Krummel DA. 2004. Food, Nutrition and Diet Therapy. Medical Nutrition Therapy in Hypertension. Di dalam: Mahan LK dan Escott-Stump S.

Kumar V, Abbas A.K, Fausto, N. 2005. Hypertensive Vascular Disease. Dalam: Robn and Cotran Pathologic Basis of Disease. Philadelpia: Elsevier Saunders.

Price, Wilson. 2006. Patofisiologi Volume 2. Jakarta: EGC.

Ridwan, M. 2009. Mengenal, Mencegah, Mengatasi Silent Killer Hipertensi. Jawa Tengah: Pustaka Widyamara.

Rumu, S. 2007. Perbedaan Tingkat Konsumsi Karbohidrat dan Lemak dengan Kejadian Hipertensi pada Lansia di Perumahan "Kusumawardani" dan Panti Wredha Pucang Gading Semarang. Jurnal Kesehatan Volume 6. No. 2. Hal. 30-38.

Shapo L, Pomerleau J, McKee M. 2003. Epidemiology of Hypertension and Associated Cardiovascular Risk Factor in a Country in Transition. Albania: Journal Epidemiology Community Health Volume 23. No. 57 Hal 734-739.
Simons-Morton GD, Hunsberger AS, horn VL, Barton AB, Robson MA, McMahon PR, et al. 2006. Nutrient intake and Blood Pressure in the Diettary Intervention Study in Children. Journal Health, Volume 17. No. 4. P 151-185.

Sugianty, Derris. 2008. Hubungan Asupan Karbohidrat, Protein, Lemak, Natrium dan Serat dengan Tekanan Darah pada Lansia. Journal of Nutrition College, Volume 1, Nomor 1, Halaman 700-714.

Sugihartono, Aris. 2007. Tesis Faktor-Faktor Risiko Hipertensi Grade II pada Masyarakat (Studi Kasus di Kabupaten Karanganyar). Semarang: Program Studi Magister Epidemiologi Pasca Sarjana UNDIP.

Sulistiani, Widi. 2005. Skripsi Analisis Faktor Risiko Yang Berkaitan Dengan Kejadian Hipertensi Pada Lansia Di Wilayah Kerja Puskesms Kroya I Kabupaten Cilacap Tahun 2005. Semarang: FKM UNDIP.

Vilareal, 2008. Hypertension. A Wiley Media Publication. New york.

Yogiantoro, Muhammad. 2006. Hipertensi Essensial dalam Ilmu Penyakit Dalam Jilid I Edisi IV. Depok: FKUI.

Zuhro A, Endang SW, Faudiyah N. Hubungan Asupan Lemak (Lemak Jenuh, Tak Jenuh, Kolesterol) dan Natrium terhadap Tekanan Darah pada Pasien Hipertensi di Poli Penyakit Dalam RSP Batu. Jurnal Manajemen Pelayanan Kesehatan, Volume 10. No. 3 Hal. 36-40. 